JBL 137, no. 4 (2018): 833-851

doi: http://dx.doi.org/10.15699/jbl.1374.2018.452196

\title{
The Gods-Complaint: Psalm 82 as a Psalm of Complaint
}

\author{
DANIEL MCCLELLAN \\ dan.mcclellan@gmail.com \\ University of Exeter, Exeter EX4 4RJ, UK
}

\begin{abstract}
Psalm 82 has long resisted a consensus regarding its genre. While some scholars have noted that the psalm's language overlaps with that of the complaint genre, several features of the psalm appear to complicate that reading. As a result, the framework of the divine council is frequently given interpretive priority, which has resulted in a variety of solutions to the psalm's several interpretive difficulties and has also contributed to a general reluctance to consider the psalm within the literary context of the psalms of Asaph. I argue that the psalm's interpretive difficulties are best resolved by understanding the psalm as a complaint, specifically a complaint put into the mouth of YHWH and addressed to the gods of the nations-a "gods-complaint." This reading provides a new interpretive framework that may help resolve important questions related to the psalm's compositional background, rhetorical function, and theological influence.
\end{abstract}

The unique mythological themes of Ps 82 have long compelled scholars to consider it apart from the other psalms of the Asaph collection. ${ }^{1}$ For many, the

${ }^{1}$ The literature on Ps 82 is phenomenally broad, but some notable contributions include Julian Morgenstern, “The Mythological Background of Psalm 82," HUCA 14 (1939): 29-126; James S. Ackerman, "An Exegetical Study of Psalm 82: A Thesis" (ThD diss., Harvard University, 1966); Gerald Cooke, "The Sons of (the) God(s)," ZAW 35 (1964): 29-34; Matitiahu Tsevat, "God and the Gods in Assembly: An Interpretation of Psalm 82," HUCA 40 (1969): 123-37; HansWinfried Jüngling, Der Tod der Götter: Eine Untersuchung zum Psalm 82, SBS 38 (Stuttgart: Katholisches Bibelwerk, 1969); Herbert Niehr, "Götter oder Menschen-eine falsche Alternative: Bemerkungen zu Ps 82," ZAW 99 (1987): 94-98; Simon B. Parker, “The Beginning of the Reign of God: Psalm 82 as Myth and Liturgy," RB 102 (1995): 532-59; Mark S. Smith, God in Translation: Deities in Cross-Cultural Discourse in the Biblical World, FAT 57 (Tübingen: Mohr Siebeck, 2008), 131-39; Peter Machinist, "How Gods Die, Biblically and Otherwise: A Problem of Cosmic Restructuring," in Reconsidering the Concept of Revolutionary Monotheism, ed. Beate Pongratzאלהים Leisten (Winona Lake, IN: Eisenbrauns, 2011), 189-240; James M. Trotter, "Death of the in Psalm 82," JBL 131 (2012): 221-39, https://doi.org/10.2307/23488222; Brent A. Strawn, “The Poetics of Psalm 82: Three Critical Notes along with a Plea for the Poetic," RB 121 (2014): 21-46. 
interaction with other divine beings, the possible distinction between YHWH and $\mathrm{El}$, and possible links with the northern tradition have suggested a very early date of composition. ${ }^{2}$ This would set the psalm apart from Pss 74 and 79 , which appear to mention the destruction of the temple in Jerusalem and are often dated to the exilic or postexilic periods. ${ }^{3}$ Indeed, Ps 82 is frequently interrogated in isolation from the rest of the psalms and by scholars interested primarily in what the psalm may reveal regarding much earlier Israelite conceptualizations of the divine council and of YHWH and El. ${ }^{4}$ These scholars largely consider the divine council typescene to be the most salient literary framework, with the psalm's likely liturgical setting providing a functional backdrop. ${ }^{5}$

In order to avoid awkward circumlocutions and confusion with the frequent references to plural deities, and in light of the unilateral use of masculine verbs and pronouns in the discussed texts, I use masculine pronouns in reference to YHWH throughout this article. Translations are my own unless otherwise noted.

${ }^{2}$ The Tetragrammaton nowhere appears in Ps 82, but, with the vast majority of readers, I understand the appellative אלהים to refer to YHWH, as it explicitly does in the surrounding psalms. The marked preference for יהוה over יהלהים in Pss 42-83 has long been taken as an indication of the redactional obscuring of יהוה (which still appears forty-nine times), but the explanations for the inconsistency vary, and there is no textual support for that conclusion. I consider the question an open one. See Matthias Millard, "Zum Problem des elohistischen Psalters: Überlegungen zum Gebrauch von יהוה und אלהים im Psalter," in Der Psalter in Judentum und Christentum, ed. Erich Zenger and Norbert Lohfink, HBS 18 (Freiburg im Breisgau: Herder, 1998), 75-110; Laura Joffe, “The Elohistic Psalter: What, How and Why?," SJOT 15 (2001): 142-69; Frank-Lothar Hossfeld and Erich Zenger, "The So-Called Elohistic Psalter: A New Solution for an Old Problem," in A God So Near: Essays on Old Testament Theology in Honor of Patrick D. Miller, ed. Brent A. Strawn and Nancy R. Bowen (Winona Lake, IN: Eisenbrauns, 2003), 35-51; Joel S. Burnett, "Forty-Two Songs for Elohim: An Ancient Near Eastern Organizing Principle in the Shaping of the Elohistic Psalter," JSOT 31 (2006): 81-101.

${ }^{3}$ Some scholars identify the "sanctuary" (קדש) and meeting places mentioned in Ps 74:3 with cultic sites in the northern kingdom, which would facilitate a preexilic date for the psalm. See Michael D. Goulder, The Psalms of Asaph and the Pentateuch: Studies in the Psalter, III, JSOTSup 233 (Sheffield: Sheffield Academic, 1996), 36; Beat Weber, "Zur Datierun der AsaphPsalmen 74 und 79," Bib 81 (2000): 521-32.

${ }^{4}$ The view that YHWH and $\mathrm{El}$ are distinguished in the psalm is promoted by Karl Budde, “Ps. 82:6f," JBL 40 (1921): 41-42, https://doi.org/10.2307/3259401; Otto Eissfeldt, "El and Yahweh," JSS 1 (1956): 29-30; Parker, "Beginning of the Reign of God"; Mark S. Smith, The Origins of Biblical Monotheism: Israel's Polytheistic Background and the Ugaritic Texts (Oxford: Oxford University Press, 2001), 48-49; David Frankel, “El as the Speaking Voice in Psalm 82:6-8," JHebS 10 (2010), art. 16, pp. 1-24, https://doi.org/10.5508/jhs.2010.v10.a16; and Ellen White, Yahweh's Council: Its Structure and Membership, FAT 2/65 (Tübingen: Mohr Siebeck, 2014), 24-33. Against these, see Tzevat, "God and the Gods in Assembly," 127-29; Michael S. Heiser, "The Divine Council in Late Canonical and Non-Canonical Second Temple Jewish Literature" (PhD diss., University of Wisconsin-Madison, 2004), 79-82.

${ }^{5}$ On the divine council type-scene, see E. Theodore Mullen, The Assembly of the Gods: The Divine Council in Canaanite and Early Hebrew Literature, HSM 24 (Chico, CA: Scholars Press, 1980); David M. Fleming, “The Divine Council as Type Scene in the Hebrew Bible" (PhD diss.,

This article was published in JBL 137/4 (2018) 833-851, copyright @ 2018 by the Society of Biblical Literature. To purchase copies of this issue or to subscribe to JBL, please contact SBL Customer Service by phone at 866-727-9955 [toll-free in North America] or 404-727-9498, by fax at 404-727-2419, or visit the online SBL Store at www.sbl-site.org. 
On the other hand, Ps 82 aligns well with the themes of the Asaphite collection, and the terminology in the psalm overlaps significantly with that of the other Asaphite psalms. Form-critical analyses have largely been confined to commentaries and monographs focused on individual collections of psalms, but even there scholars have posited a wide variety of genres, including "prophetic liturgy," "prophetic oracle," "report of trial," and even "a peculiar mixing of psalm and oracle, where the oracle is the chief thing but is organically fitted into a short prayer." $\mathrm{A}$ review of the notoriously broad scholarship reveals that the psalm has long resisted a consensus regarding genre as well as interpretation.

In this article, I argue that the interpretive difficulties of Ps 82 can be resolved by understanding the psalm as a complaint, and more specifically a "godscomplaint" put into the mouth of YHWH and directed at the gods of the nations. Following a discussion of the traditional approaches to Ps 82 and its interpretive difficulties and the complaint genre (using Ps 74 as a case study), I will interrogate Ps 82 using the complaint framework as an interpretive lens. I will argue that this particular framework facilitates the most parsimonious reading of the text, as well as a resolution to a number of the psalm's long-standing interpretive challenges. Finally, I will make some observations regarding what the framework may reveal about the psalm's composition and rhetorical function.

\section{Conventional Approaches to Psalm 82}

The most common interpretations of Ps 82 frame the psalm as a visionary account of a scene in the divine council. In verse 1, the God of Israel stands among the gods of the nations to accuse and condemn them. Most interpretations tend toward understanding the interrogatives of verse 2 to be accusatory questions, which are then followed in verses $3-4$ by declarations of divine responsibilities for upholding justice. ${ }^{7}$ The fifth verse is usually understood to be some manner of

Southern Baptist Theological Seminary, 1989); Min Suc Kee, "The Heavenly Council and Its TypeScene," JSOT 31 (2007): 259-73; Robert P. Gordon, "Standing in the Council: When Prophets Encounter God," in The God of Israel, ed. Robert P. Gordon, UCOP 64 (Cambridge: Cambridge University Press, 2007), 190-204.

${ }^{6}$ For prophetic liturgy, see Mitchell Dahood, Psalms, 3 vols., AB 16-17A (Garden City, NY: Doubleday, 1968), 268. For prophetic oracle, see Craig C. Broyles, Psalms, NIBCOT 11 (Peabody, MA: Hendrickson, 1999), 335. For report of trial, see Erhard S. Gerstenberger, Psalms: Part 2 and Lamentations, FOTL 15 (Grand Rapids: Eerdmans, 2001), 113. Gerstenberger gives a second designation, "Praise and Petition," which is related to Broyles's broad division of the psalms into "praise and lament, or praise and petition" (The Conflict of Faith and Experience in the Psalms: A Form-Critical and Theological Study, JSOTSup 52 [Sheffield: JSOT Press, 1989], 35-36). For a "peculiar mixing of psalm and oracle," see Sigmund Mowinckel, The Psalms in Israel's Worship, trans. D. R. Ap-Thomas, 2 vols. (Oxford: Blackwell, 1962), 2:64.

${ }^{7}$ The question in verse 2 is labeled a "reproachful question" by Erich Zenger (in Frank-Lothar

This article was published in JBL 137/4 (2018) 833-851, copyright @ 2018 by the Society of Biblical Literature. To purchase copies of this issue or to subscribe to JBL, please contact SBL Customer Service by phone at 866-727-9955 [toll-free in North America] or 404-727-9498, by fax at 404-727-2419, or visit the online SBL Store at www.sbl-site.org. 
verdict, with the prosecutor abruptly shifting address to the court or to the worshipers and announcing the gods' waywardness and incapacity to meet their duties. This is followed by the sentence in verses 6-7 consigning the gods to mortality. The petition of verse 8 calls upon YHWH to restore justice, as is his prerogative as judge over all the earth. The speaker here may be YHWH, El, the psalmist, or the community of worshipers.

While this outline roughly corresponds to the majority of readings of the psalm, there are a handful of interpretive difficulties that continue to be debated. One of the longest-standing questions has been the identity of the plural אלהים. Until about the mid-twentieth century, most scholars accepted that the אלהים were either disobedient angels or human judges referred to honorifically or metonymically as "gods" in the psalm. ${ }^{8}$ These readings were primarily motivated by theological sensitivity, but the "judges" reading was supported by the ostensibly analogous use of אלהים in reference to humans in Exod 21:6 and 22:7, as well as by the claim that the neglected responsibilities mentioned in verses $2-4$ were the primary purview of human kings and judges. ${ }^{9}$ The latter has been recently adduced by James M. Trotter in support of his argument that the אלהים are best understood as the kings of the nations, who were considered divine by their constituents. ${ }^{10}$

Perhaps the most compelling question for contemporary scholars of early Israelite theology is the psalm's possible distinction of YHWH from El. Scholars have argued for some time now that in the earliest recoverable literary strata,

Hossfeld and Erich Zenger, Psalms 2: A Commentary on Psalms 51-100, trans. Linda M. Maloney, Hermeneia [Minneapolis: Fortress, 2005], 333) and an "indictment in the form of a question" by Marvin Tate (Psalms 51-100, WBC 20 [Dallas: Word, 1990], 335).

${ }^{8}$ Most precritical exegetes understood the gods of the narrative to be human judges, but on the weakness of that traditional reading, see Cooke, "Sons of (the) God(s)," 29-34; Tsevat, "God and the Gods in Assembly," 123-37. For a representative nineteenth-century voice, see Franz Julius Delitzsch, Biblischer Commentar über die Psalmen, BKAT (Leipzig: Dörffling \& Franke, 1894), 546-49.

${ }^{9}$ On the problems with reading אלהים as a reference to humans in the Exodus verses, see Cyrus Gordon, “אלהיםin Its Reputed Meaning of Rulers, Judges," JBL 54 (1935): 139-44, https:// doi.org/10.2307/3259316; Anne E. Draffkorn, "Ilāni/Elohim," JBL 76 (1957): 216-24, https://doi .org/10.2307/3261571; David P. Wright, Inventing God's Law: How the Covenant Code of the Bible Used and Revised the Laws of Hammurabi (Oxford: Oxford University Press, 2009), 133-37 (and n. 57), 245-48, 252-58. For a somewhat recent attempt to defend the traditional view, see J. Robert Vannoy, "The Use of the Word hä $\bar{a}^{x}$ lohîm in Exodus 21:6 and 22:7, 8," in The Law and the Prophets: Old Testament Studies Prepared in Honor of Oswald Thompson Allis, ed. John H. Skilton, Milton C. Fisher, and Leslie W. Sloat (Philadelphia: Presbyterian and Reformed Publishing, 1974), 22541.

${ }^{10}$ Trotter, "Death of the אלהים in Psalm 82," 221-39. The similar notion that the psalm can be thought of as referring to divine rule administered by human rulers is promoted in Niehr, “Götter oder Menschen," 94-98; Tate, Psalms 51-100, 341; Gerstenberger, Psalms, 114. Another minority view is that the psalm conflates two chronologically distinct perspectives, which is argued by Morgenstern, "Mythological Background," 114-26; A. Gonzalez, "Le Psaume LXXXII," VT 13 (1963): 293-309; and, to some degree, Tsevat, "God and the Gods in Assembly," 134.

This article was published in JBL 137/4 (2018) 833-851, copyright ( 2018 by the Society of Biblical Literature. To purchase copies of this issue or to subscribe to JBL, please contact SBL Customer Service by phone at 866-727-9955 [toll-free in North America] or 404-727-9498, by fax at 404-727-2419, or visit the online SBL Store at www.sbl-site.org. 
YHWH was understood to be a second-tier deity subordinate to the high god El. The clearest attestation of this hierarchy is found in the version of Deut 32:8-9 preserved in 4QDeut ${ }^{j}$ (4Q37) and reflected in most ancient Greek translations of the passage. ${ }^{11}$ According to the reconstruction of the text supported by those versions, the nations of the earth were divided up by Elyon "according to the number of the children of God," with the nation of Israel/Jacob going to YHWH, one of those children. Psalm 82 is considered an additional witness to this divine hierarchy. Among other considerations, verse 6 uniquely calls the deities "children of Elyon," which may obliquely allude to the distinction of the two deities in Deut 32:8. Additionally, the אלהים of verse 1 is/are taking a stand among the gods, while the אלהים of verse 8 is/are called upon to rise from an ostensible sitting position. According to the conventions of the type-scene, we are told, the presiding deity would have remained seated during the council, with a subordinate deity standing to act as prosecutor. ${ }^{12}$ Others point out, however, that the evidence is mixed regarding the postures of judgment. ${ }^{13}$ Recent analyses have suggested that the distinction between the two deities in the psalm may not be so clear. ${ }^{14}$

The identities of the speakers in verses 5 and 8 are also open questions. The former verse is widely understood as some manner of verdict being passed on the

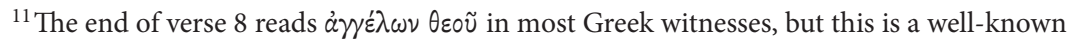
substitution for the Hebrew בני אלהים. 4QDeut confirms this reconstruction, and the earliest known Greek witness reads "children of God" (John William Wevers, Notes on the Greek Text of Deuteronomy, SCS 39 [Atlanta: Scholars Press, 1995], 513). The beginning of verse 9 has xai $\dot{\varepsilon} \gamma \varepsilon \nu \eta^{\prime} \theta \eta$ in the Greek, which suggests ויהי in the source text. On this passage, see Patrick W. Skehan, "A Fragment of the 'Song of Moses' (Deut. 32) from Qumran," BASOR 136 (1954): 12-15; Paul Sanders, The Provenance of Deuteronomy 32, OtSt 37 (Leiden: Brill, 1996), 155-59; Michael S. Heiser, "Deuteronomy 32 and the Sons of God," BSac 158 (2001): 52-74; Innocent Himbaza, "Dt 32,8, une correction tardive des scribes: Essai d'interprétation et de datation," Bib 83 (2002): 527-48; Jan Joosten, "A Note on the Text of Deuteronomy xxxii 8," VT 57 (2007): 548-55; Smith, God in Translation, 139-43, 195-212.

${ }^{12}$ Kee "Heavenly Council," 263-68; Smith, God in Translation, 133 n. 4. Cf. Heiser, "Divine Council," 79-82.

${ }^{13}$ See, e.g., Machinist, “How Gods Die," 199-200.

${ }^{14}$ Smith, God in Translation, 135-36; Machinist, "How Gods Die," 195-203, esp. 203 and n. 41. Both highlight the possibility that the scene is an archaizing borrowing of older motifs. Some understand בעדת־ in verse 1 (literally, "in the council of El") to indicate that El presides over the council in which YHWH pleads his cause, but this case is not strong. The designation El is used in reference to YHWH repeatedly throughout the Hebrew Bible, and it may just as well be a fixed or frozen formula. El's functional invisibility as a separate deity also argues against the distinction (also noted by both Smith and Machinist). Additionally, the LXX's $\sigma u v \alpha \gamma \omega \gamma \tilde{\eta}$ $\theta \varepsilon \tilde{\omega} \nu$ suggests an original עדת־אלים (Gonzalez, "Le Psaume LXXXII," 299; Tate, Psalms 51-100, 329 n. 1.d; cf., with some reservation, Oswald Loretz, Psalmstudien: Kolometrie, Strophik und Theologie ausgewählter Psalmen, BZAW 309 [Berlin: de Gruyter, 2002], 259). Finally, the psalms of Asaph already conflate YHWH/Elohim and El/Elyon (Pss 74:7-8, 18; 77:8-10; 78:35, 56; 83:2, 19). If the provenance of the psalm and its rhetorical function within the psalms of Asaph for which I argue below is correct, a distinction between the two deities can hardly be asserted.
}

This article was published in JBL 137/4 (2018) 833-851, copyright ( $\odot 2018$ by the Society of Biblical Literature. To purchase copies of this issue or to subscribe to JBL, please contact SBL Customer Service by phone at 866-727-9955 [toll-free in North America] or 404-727-9498, by fax at 404-727-2419, or visit the online SBL Store at www.sbl-site.org. 
gods (although some understand the group referred to as "they" to be the wicked, whom the gods favor).${ }^{15}$ Is the prosecuting deity addressing the rest of the council and referring to the gods in the third person? Is it the psalmist addressing the worshipers? Is it the presiding deity rendering a decision? There has not been wide agreement. The eighth verse is understood to call upon YHWH to establish justice over the earth, but within the divine council framework it is not entirely clear who is speaking. The question is not so widely debated in this verse, but David Frankel raises the possibility that the speaking voice in the psalm shifts from YHWH in verses $1-5$ to $\mathrm{El}$ in verses $6-8$. According to this reading, verse 5 is the concluding judgment of $\mathrm{YHWH}$, and $\mathrm{El}$ takes over speaking with verse 6 , rendering the judgment and calling upon YHWH to take over control of the nations. ${ }^{16}$

A final concern relates to the exact function of the language of verses 6-7. Here the gods are sentenced to mortality, but the structure is peculiar for the passing of a sentence:

$$
\begin{aligned}
& 6 \text { a אני־אמרתי אלהים אתם I say, "You are gods, } \\
& \text { b children of the Most High, all of you"; } \\
& 7 \text { a nevertheless, you shall die like mortals, }
\end{aligned}
$$

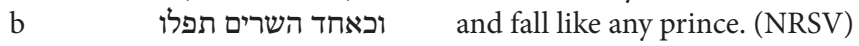

Elsewhere in the Hebrew Bible, אמרת and appear together where a misunderstanding finds correction or ignorance finds enlightenment (e.g., Zeph 3:7, Ps 31:22). Since Karl Budde's article in 1921, the psalm has been frequently interpreted to mean that the divine judge was-perhaps sarcastically-mistaken in thinking them deities. ${ }^{17}$ This reading has not been widely accepted, but the most likely meaning-that the immortality of the gods is being revoked-represents a rather uncharacteristic use of the construction. ${ }^{18}$

\section{The Complaint Genre}

Jonathan Culler has asserted, "A work can only be read in connection with or against other texts, which provide a grid through which it is read and structured by establishing expectations which enable one to pick out salient features and give

\footnotetext{
${ }^{15}$ See, e.g., Goulder, Psalms of Asaph, 164: "The They of v. 5 are the רשעים, the wicked of v. 4." For a more "standard" perspective, see Tsevat, "God and the Gods in Assembly," 128-29.

${ }^{16}$ Frankel, "El as the Speaking Voice," 1-24. A similar conclusion is reached in White, Yahweh's Council, 33.

${ }^{17}$ Budde, "Ps. 82:6f," 39-42. Cf. Yair Zakovitch, "Psalm 82 and Biblical Exegesis," in Sefer Moshe: The Moshe Weinfeld Jubilee Volume; Studies in the Bible and the Ancient Near East, Qumran, and Post-Biblical Judaism, ed. Chaim Cohen, Avi Hurvitz, and Shalom M. Paul (Winona Lake, IN: Eisenbrauns, 2004), 213-28, here 222-24.

${ }^{18}$ See, e.g., Tsevat, "God and the Gods in Assembly," 129-30; Tate, Psalms 51-100, 330 n. 6 a.
} 
them a structure." 19 Similarly, Harry P. Nasuti writes in his study on genre in the Psalms that "it is only through association with other texts that one knows how to approach any particular text." 20 Both of these quotations get at the fact that hearers and readers construct meaning for texts by imposing certain expectations and conceptual structures based on the presence of conventionalized literary forms. As a basic example, if a modern text begins with "Once upon a time," an informed English-speaking reader will immediately assume a number of things about the text's intended form and function and will adopt a set of interpretive lenses related to those assumptions. While there are a number of different ways to conceptualize genre and its form, function, and study, it can be used to refer generally to a culturally salient grouping of those conventionalized forms, and this is how I use the term here.

I am concerned specifically with the literary forms understood to reify the genre of the complaint, specifically as found in the Psalms. ${ }^{21}$ This is a modern framework that scholars apply to ancient texts, and therefore firm and clear boundaries should not be assumed. ${ }^{22}$ There have been a handful of studies that have produced models for the psalm of complaint, and they overlap significantly in their identification of prototypical features. The model I adopt is a broadly representative one promoted by Craig C. Broyles. ${ }^{23}$ For Broyles, the complaint is a subgenre within the broader genre of the lament, which is generally understood as a literary vehicle for the expression of grief or sorrow accompanied by a request for divine intervention. The complaint is related to the lament, but, rather than focus on the larger situation, the complaint concentrates on the responsible party, often striking a

${ }^{19}$ Jonathan D. Culler, Structuralist Poetics: Structuralism, Linguistics and the Study of Literature (Ithaca, NY: Cornell University Press, 1975; new ed., London: Routledge, 2002), 163.

${ }^{20}$ Harry P. Nasuti, Defining the Sacred Songs: Genre, Tradition and the Post-Critical Interpretation of the Psalms, JSOTSup 218 (Sheffield: Sheffield Academic, 1999), 52-53.

${ }^{21}$ I roughly espouse a prototype approach to genre, which is related to Wittgenstein's "family resemblances" approach. For two helpful discussions related to these approaches, see Carol A. Newsom, "Pairing Research Questions and Theories of Genre: A Case Study of the Hodayot," DSD 17 (2010): 241-59; Robert Williamson Jr., "Pesher: A Cognitive Model of the Genre," DSD 17 (2010): 307-31. For prototype theory in general, see Eleanor Rosch and Barbara B. Lloyd, eds., Cognition and Categorization (Hillsdale, NJ: Erlbaum, 1978); John R. Taylor, Linguistic Categorization: Prototypes in Linguistic Theory, 2nd ed. (Oxford: Clarendon, 1995).

${ }^{22}$ In fact, one of my primary concerns with the conventional approaches to genre vis-à-vis Ps 82 has been the assertion of necessary and sufficient features in the drawing of strict boundaries. As an example, Frankel insists that Ps 82 cannot be a complaint because "there is no atmosphere of distress or anguish in it" ("El as the Speaking Voice," 9; see also n. 39 below).

${ }^{23}$ Broyles, Conflict of Faith. For a discussion of the Psalter's laments and their relationship to the broader literary genre, see Carleen Mandolfo, "Language of Lament in the Psalms," in The Oxford Handbook of the Psalms, ed. William P. Brown (Oxford: Oxford University Press, 2014), 114-30. Susan Niditch includes an insightful discussion of the autobiographical dimensions of the lament in The Responsive Self: Personal Religion in Biblical Literature of the Neo-Babylonian and Persian Periods, AYBRL (New Haven: Yale University Press, 2015), 55-63.

This article was published in JBL 137/4 (2018) 833-851, copyright ( 2018 by the Society of Biblical Literature. To purchase copies of this issue or to subscribe to JBL, please contact SBL Customer Service by phone at 866-727-9955 [toll-free in North America] or 404-727-9498, by fax at 404-727-2419, or visit the online SBL Store at www.sbl-site.org. 
rebuking tone. ${ }^{24}$ Broyles identifies six features of the complaint: (1) the Godlament, (2) the confession of trust, (3) the reference to God's earlier saving deeds, (4) narrative and hymnic praise, (5) the petition, and (6) the assurance of being heard.

The individual features of the complaint are expressed in conventionalized ways, as well. The focal point of the complaint, the "God-lament," addresses YHWH's role in the distress, whether concessive or causative, usually through accusations, rhetorical questions, or both. ${ }^{25}$ The two most common rhetorical questions employ the interrogative particles למה ("why?") and עד־מתי ("how long?"). The former rhetorically highlights the inexplicable nature of YHWH's actions or lack thereof, with the latter imposing a sense of urgency upon the complaint. The "confession of trust" is a rarer element of the complaint, and it offers praise regarding the deity's nature or regarding the deity's actions relevant to the distress under consideration. Very closely related is the assurance of being heard, which, according to Broyles, depicts YHWH's response to the complaint (שמע יהוה ["YHWH has heard"] in three of the four occurrences), and therefore is not a constituent element of the complaint proper. More common is the "reference to God's earlier saving deeds," which recounts YHWH's deliverance of his people in the past. That deliverance is usually related to the current suffering, and rhetorically "draw [s] out the contrast between the glorious past and the woeful present." ${ }^{26}$ This juxtaposition serves rhetorically to express confidence that YHWH is capable of tackling the current situation while also reminding YHWH that he has yet to do so. The petition is another critical feature of the complaint, and in it the psalmist uses imperatives and negative jussives to appeal to YHWH for relief, whether through direct intervention or through the cessation of whatever neglectful or harmful treatment on the part of YHWH the psalmist sees as facilitating the people's suffering. ${ }^{27}$

Psalm 74 is a fairly standard example of a psalm of complaint. Its twenty-three verses are traditionally divided into three segments comprising verses 1-11, 12-17, and 18-23. The first section contains the bulk of the "complaint," addressing the destruction of the Jerusalem temple and the concomitant tragedies. The descriptions of the horrors visited upon YHWH's people by the unnamed enemy in verses 3b-9 are framed with the genre's stock rhetorical questions, למה ("why?"; vv. 1, 11) and עד־מתי ("how long?”; v. 10), as well as with the petitions taking the standard imperative form: זכר (“Remember!”; v. 2), הרימה פעמיך (“Lift up your steps!”; v. 3),

\footnotetext{
${ }^{24}$ Broyles, Conflict of Faith, 40: "Laments can be addressed to anyone; complaint must be addressed to the one responsible. A lament focuses on a situation; a complaint focuses on the one responsible. A lament simply bemoans the state of things; a complaint contains a note of blame and rebuke."

${ }^{25}$ Ibid., 55-82.

${ }^{26}$ Ibid., 42.

${ }^{27}$ Ibid., 46-48.
} 
and כלה ("Destroy!"; v. 11). ${ }^{28}$ The complaint is constituted by the rhetorical questions and the imperatives and jussives, as well as by the description of the enemy's actions with the resulting lamentable state of affairs. It has been noted by scholars that the complaint within Ps 74 reflects a heightened sense of urgency, omitting the initial invocation and fronting the rhetorical questions. In an effort to draw out a favorable response, the psalmist appeals to YHWH's concern for his own people and to the relationship established with them.

The second section, verses $12-17$, abruptly shifts attention to proclaiming YHWH's mythopoetic creative acts, which are introduced as his "working salvation in the midst of the earth" (פעל ישועות בקרב הארץ; v. 12). The vav at the beginning of verse 12 is understood as an adversative-emphatic "Nevertheless!", which changes the tone in an effort to reassure YHWH that the complainant recognizes his power and mercy and knows he can remedy the situation. Within the complaint framework, this section functions as the "reference to God's earlier saving deeds," which may account for the framing of creation as salvific. ${ }^{29}$ The introductory ("of old") and the acts described in the section hark back to Israel's mythological past, invoking Leviathan and the serpents of the primordial waters of chaos (cf. Isa 27:1; KTU 1.5 i.1-3, 27-30). ${ }^{30}$ The allusion to YHWH's power over primordial monsters, combined with the organizational acts described in verses 15-17, suggests that the psalmist is recalling YHWH's power to render life and order out of chaos and disorder, which power is directly relevant to the chaos that has devastated the land of Israel. ${ }^{31}$

The final and shortest section of the psalm, comprising verses $18-23$, resumes the petitions for YHWH's mercy and intervention, this time appealing to YHWH's sense of pride, covenant, and justice, alternating between imperatives and negative jussives in calling upon the deity to meet his obligations to his people. Here the additional motif of the is included with the emphatic petition, "Rise up, O God! Plead your case!" (קומה אלהים ריבה ריבך). ${ }^{32}$ Erich Zenger states that this clause,

${ }^{28}$ Occurrences of נחלה ("inheritance"; v. 2), משכן־שמך ("dwelling place of your name"; v. 7), and the verb קנה ("acquire"; v. 2) in reference to Israel reflect the Deuteronomistic foundation of the author's conceptualization of YHWH's relationship with Israel. See Rainer Albertz, Israel in Exile: The History and Literature of the Sixth Century B.C.E., trans. David Green, SBLStBL 3 (Atlanta: Society of Biblical Literature, 2003), 142-43; Hossfeld and Zenger, Psalms 2, 245; Marko Marttila, “The Deuteronomistic Heritage in the Psalms," JSOT 37 (2012): 78-79.

${ }^{29}$ On the "reference to God's earlier saving deeds," see Broyles, Conflict of Faith, 42-43.

${ }^{30}$ Nathaniel E. Greene has recently argued that this section is an interpolation that draws upon much earlier ideology ("Creation, Destruction, and a Psalmist's Plea: Rethinking the Poetic Structure of Psalm 74," JBL 136 [2017]: 85-101, https://doi.org/10.15699/jbl.1361.2017.156672).

${ }^{31}$ Walter Brueggemann and William H. Bellinger Jr., Psalms, NCBiC (Cambridge: Cambridge University Press, 2014), 323.

${ }^{32}$ The imperative קומה is found in over a dozen other laments, including eight other psalms where YHWH is the subject (Pss 3:8, 7:7, 9:20, 10:12, 17:13, 35:2, 44:27, 132:8). See J. Gamberoni, “קוּסוּ, TDOT 12:605-6.

This article was published in JBL 137/4 (2018) 833-851, copyright ( 2018 by the Society of Biblical Literature. To purchase copies of this issue or to subscribe to JBL, please contact SBL Customer Service by phone at 866-727-9955 [toll-free in North America] or 404-727-9498, by fax at 404-727-2419, or visit the online SBL Store at www.sbl-site.org. 
"challenges YHWH, as saving judge, now at last to exercise his twofold office, namely effecting justice in the cosmos and in his people, against the oppressors and for the oppressed-out of mercy for the victims of injustice to judge or effect rescue." ${ }^{33}$

As has been noted by many scholars, this psalm is "in best accordance with the general scheme of Communal ComplainT." ${ }^{34}$ I have already noted the omission of the invocation, but two other elements of the complaint that we do not find in Ps 74 are the confession of trust and the assurance of being heard (cf. Pss 79:13, 80:19). The withholding of praise rhetorically challenges YHWH to do what has been done in the past, which punctuates the psalmist's desperation and the severity of the situation. This adds a rhetorical dynamic that we may find unexpected and even jarring, but in many ways the complaint functions precisely to question the integrity and justice of the moral framework over which YHWH has sovereignty. If Job's antagonists accurately reflect the then-contemporary conventional wisdom regarding the cosmic reciprocity of righteousness up to the exilic period, then those who diligently strive to serve YHWH have an honest case when they demand to know why he has not delivered. YHWH is either withholding what is owed, willfully ignoring the suffering of the righteous, setting his hand against them, or has forgotten his covenant and his people. The petitions and accusatory questions of the psalms of complaint raise all these possibilities and demand that YHWH make his people whole. Walter Brueggemann refers to these psalms as "Psalms of Disorientation" and describes them as responding to the failure of the system by seeking to reorient or restructure it. ${ }^{35}$ Nasuti states that "those psalms that contend that the problem with the relationship is on God's part raise the unsettling possibility that the system itself has broken down." ${ }^{6}$ To whom can the righteous turn if even the Most High either cannot or will not uphold justice and deliver the oppressed?

\section{Psalm 82 as a Psalm of Complaint}

One main reason Ps 82 has resisted classification as a complaint is that this classification makes it difficult to prioritize the divine council framework. The fact that segments of Ps 82 are closely linked with, or are to be identified as, elements of the complaint genre is acknowledged by a number of scholars, even as they insist that the conceptual space of the divine courtroom is to be foregrounded. Marvin Tate comments, for instance, "'How long?' (עד־מתי) is an expression found in some laments.... Here, however, the question has the character of a charge against the

${ }^{33}$ Zenger, Psalms 2, 250.

${ }^{34}$ Gerstenberger, Psalms, 79.

${ }^{35}$ Walter Brueggemann, The Message of the Psalms: A Theological Commentary, Augsburg Old Testament Studies (Minneapolis: Augsburg, 1984), 51-121.

${ }^{36}$ Nasuti, Defining the Sacred Songs, 70. 
gods." ${ }^{37}$ Psalms of lament are themselves frequently described as charges against God, however, so this is a distinction without a difference. ${ }^{38}$ The notion of a psalm of complaint set in the mouth of God has rarely been considered. ${ }^{39}$

While Ps 82 is only eight short verses, its structure and terminology are strikingly similar to those of Ps 74. As in Ps 74, the very first word addressed to the object of the complaint is the interrogative particle of a two-part accusatory rhetorical question: "How long [עד־מתי] will you render unjust judgment and show partiality to the wicked?" In Ps 74, the rhetorical questions of verse 1 are followed by imperatives intended to bring to God's attention his responsibility for the wellbeing of his people, which has been compromised. The remaining verses of the first section describe the lamentable state of affairs. Similarly, Ps 82:3-4 contains a series of imperatives intended to bring to the attention of the gods of the nations the proper administration of justice, which has likewise been compromised.

Psalm 82:5 has long been understood as a verdict, but, through the interpretive lens of the complaint, it makes more sense to view the verse as the consequence of the gods' neglect. Elsewhere in the Psalms, the foundations of the earth are set in place by YHWH and preserved by his administration of the cosmic order (Pss 93:1, 96:10, 104:5). Psalm 82 views that responsibility as shared by the gods, and the author indicts them rather than YHWH. As Patrick D. Miller has stated, "the maintenance of justice and righteousness is the foundation of the universe, the responsibility of the divine council, and the issue upon which hang both the stability of the universe and the stability and effective reality of the divine world." ${ }^{40}$ For

${ }^{37}$ Tate, Psalms 51-100, 329. Tate also identifies קומה with the complaint genre, although "it seems to be more acclamation than supplication in this context" (339). Hermann Gunkel and Joachim Begrich list the petition of Ps 82:8 with the elements of the communal complaint (Introduction to Psalms: The Genres of the Religious Lyric of Israel, trans. James D. Nogalski, Mercer Library of Biblical Studies [Macon, GA: Mercer University Press, 1998], 90; German original, 1933).

${ }^{38}$ See, e.g., Zenger, Psalms 2, 393-94 (also quoting Bernd Janowski, "Die Toten loben JHWH nicht: Psalm 88 und das alttestamentliche Todesverständnis," in Auferstehung / Resurrection: The Fourth Durham-Tübingen Research Symposium; Resurrection, Transfiguration and Exaltation in Old Testament, Ancient Judaism and Early Christianity, ed. Freidrich Avemarie and Hermann Lichtenberger, WUNT 135 [Tübingen: Mohr Siebeck, 2001], 3-45); Brueggemann and Bellinger, Psalms, 210.

${ }^{39}$ Frankel suggests that קומה "accords with" the usage in the psalm of complaint but insists that "Psalm 82 is hardly a Song of Complaint," primarily on the grounds that the complainant shows no signs of distress and it would be uncharacteristic to petition to "save the downtrodden and unfortunate of the other nations" ("El as the Speaking Voice," 9-10). One exception is a note written by Patrick D. Miller in the HarperCollins Study Bible, which states that the complaint element "how long?" is "taken up by God on behalf of the victims of oppression" (Miller, "Psalms," The HarperCollins Study Bible, rev. and updated ed., ed. Harold W. Attridge et al. [San Francisco: HarperCollins, 2006], 800). I thank the JBL editors for bringing this exception to my attention.

${ }^{40}$ Patrick D. Miller, "Cosmology and World Order in the Old Testament: The Divine Council as Cosmic-Political Symbol," HBT 9 (1987): 53-78, here 68.

This article was published in JBL 137/4 (2018) 833-851, copyright ( 2018 by the Society of Biblical Literature. To purchase copies of this issue or to subscribe to JBL, please contact SBL Customer Service by phone at 866-727-9955 [toll-free in North America] or 404-727-9498, by fax at 404-727-2419, or visit the online SBL Store at www.sbl-site.org. 
him, Ps $82: 5 b$ describes the consequence of the failure of the gods to uphold justice. ${ }^{41}$ The first part of the verse should be interpreted in the same way: because the gods in Ps 82 have been derelict in their duties, the people of the nations lack knowledge and wander in darkness. The "they" of verse 5 are the denizens of the nations of the earth, not the gods. This is also the interpretation for which Brent A. Strawn argues, although without reference to the complaint genre. ${ }^{42}$ Psalm 82:5 makes little sense as a verdict if the psalm functions as a psalm of complaint, but it fits the framework quite well as a description of the consequences of the deities' unjust judgment, favoritism, and neglect.

We must skip to verse 8 for the next complaint element, which is the petition "Rise up, O God!" (קומה אלהים). As mentioned above, the imperative קומה appears in several psalms, but there are only two occurrences in all of the Hebrew Bible with אלהים: Ps 74:22 and Ps 82:8. Here, the call to action is for YHWH to judge the earth (שפטה הארץ). The second half of the verse, אתה תנחל בכל־הגוים, could be read "You

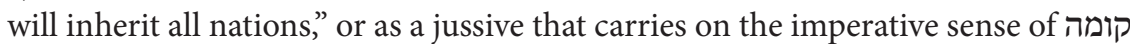
and שפטה: "You inherit all the nations." ${ }^{43}$ As in Ps 74, the petition seeks a resolution to the oppression and suffering of the poor and the needy. In both instances, only YHWH can bring about the social justice so sorely needed among the people of Israel and the nations of the earth. It is important to note that the poor, the needy, and the orphan are not the discrete and literal victims of the negligence of the gods; they are stock metonymic figures who represent idealized victims associated with conventional conceptions of social justice and cosmic order. ${ }^{44}$ The maintenance of that order was absolutely the purview of each nation's patron deity, so the argument that the victims of Ps 82 indicate that the אלהים are human rulers or ostensibly

${ }^{41}$ Ibid., 69: "The consequence of this is stated to be a shaking of the foundations of the world. The failure to maintain order, which in this instance is clearly seen to be the maintenance of righteousness in the moral sphere, that is, the resistance to a disorder that does in the poor and gives the rich and the wicked control, is seen to be manifest in a kind of cosmic disorder. The cosmos comes apart when righteousness is not maintained."

${ }^{42}$ Strawn, "Poetics of Psalm 82," 21-46. To summarize his argument: (1) the links with Isa $44: 9,18$ (often appealed to in support of reading v. 5 as a judgment on the gods) are artificial, as the author there is addressing the inability of inanimate objects to perceive anything at all, not the ignorance and waywardness of sentient deities; (2) waywardness and a lack of knowledge and understanding generally refer to the oblivious wanderings of humans without the light of divine direction (Job 14:21, 29:3, Ps 92:7, Isa 1:3, 40:21, 50:10); (3) while the closest grammatical antecedents are the gods, the objects of the imperative הצילו, "Deliver!" are elided, and they are the semantic foci of verses 3-4.

${ }^{43}$ Cf. Dahood, Psalms, 2:271; Tate, Psalms 51-100, 332.

${ }^{44}$ See Morris Silver, "Prophets and Markets Revisited," in Social Justice in the Ancient World, ed. K. D. Irani and Morris Silver, Contributions in Political Science 354 (Westport, CT: Greenwood, 1995), 182-83: "The Ancient Near East designated victims by terms more or less conventionally translated as 'orphan,' 'widow, 'poor person,' and 'peasant.' The referents are much less real-world social groupings than intellectual constructs. That is, the terms refer to the ideal victim" (emphasis original). 
divine kings does not hold. The אלהים are the patron deities of the traditional seventy nations of the earth. ${ }^{45}$

Similar to Ps 74, Ps 82 lacks the complaint template's invocation, confession of trust, and assurance of being heard. Unlike Ps 74, however, Ps 82 also lacks the reference to earlier saving deeds. Psalm 82 is not directing the complaint at YHWH, however, and the gods have no righteous deeds in their background to champion. Indeed, they are the antagonists of the entire scene. This brings us to the psalm's other literary framework. The verses I have skipped over (vv. 1 and 6-7) constitute elements not of the complaint genre but of the divine-council narrative framework that establishes the setting of the complaint within the divine assembly. Whereas in other complaints the psalmist directs his complaint to YHWH for YHWH's failure to uphold the cosmic order vis-à-vis his people, here the complaint is being put into the mouth of the prosecuting attorney in the divine council. It is directed at the gods of the nations, who have failed to uphold the cosmic order vis-à-vis their people, disrupting the integrity of the cosmic order as a whole. This is a brilliant innovation on the complaint genre that weaves the conventionalized elements of the psalm of complaint into the case presented by the God of Israel against the gods of the nations. They are the ones ultimately responsible for the failure of social justice lamented in the third section of Ps 74, and this highlights a critical observation: Ps 82 employs the divine-council setting and the complaint framework to narrate the very ריב that YHWH is called upon to prosecute in Ps 74:22.

The first verse of Ps 82 sets the council scene, describing the divine judge standing (or rising) to take his place among the gods and immediately presenting the complaint in verses $2-5$. Because the condemnation of the gods is a foregone conclusion, there can be no expectation of a favorable response. The gods are therefore condemned to mortality in short order in verses 6-7. The constraints imposed by the juxtaposition of the divine-council setting and the complaint motif account for the peculiar fact that the gods are called upon to repair the damage they have done but are given no opportunity to comply. The imperative petitions are necessary to satisfy the requirements of the complaint template, but the rhetorical goal is not to compel the gods to righteous judgment-it is, rather, to reorient the cosmos by deposing them.

The somewhat enigmatic use of אמרת and wa verses 6-7 represents the first pivot in the two-part reorientation. The deity acknowledges the divinity of the gods but immediately revokes it by divine fiat to make way for YHWH's takeover. Strawn argues that אכן represent declarative acts that had previously rendered the deities divine but now revoke that divinity. Regardless of whether

${ }^{45}$ On this number and the relationship of the nations to patron deities, see Daniel I. Block, The Gods of the Nations: Studies in Ancient Near Eastern National Theology, 2nd ed., ETSS (Grand Rapids: Baker, 2000), 28-33; Darrell D. Hannah, "Guardian Angels and Angelic National Patrons in Second Temple Judaism and Early Christianity, DCLY 2007 (2007): 413-35.

This article was published in JBL 137/4 (2018) 833-851, copyright ( 2018 by the Society of Biblical Literature. To purchase copies of this issue or to subscribe to JBL, please contact SBL Customer Service by phone at 866-727-9955 [toll-free in North America] or 404-727-9498, by fax at 404-727-2419, or visit the online SBL Store at www.sbl-site.org. 
אמרתי is understood to have divinized the gods of the nations, it is clear that verse 7 consigns them to mortality. The proximate cause of the convulsions of the cosmos has been removed. Conventional forms here provided the literary vehicles for concepts that had not yet been articulated in the literature but still needed the salience of traditional linguistic constructions-there were no literary templates for the de-deification of the divine council. ${ }^{46}$

With the work of the divine courtroom completed, the complaint elements can come back into focus. Normally, the issuer of the complaint concludes with petitions. The gods are gone in Ps 82, however, so YHWH has no one to whom he could issue the final petition. It falls back on the psalmist himself to call upon YHWH to rise up and fill the heavenly power vacuum left by the removal of the gods. Here is the rhetorical payoff of the psalm: YHWH alone will rule over the nations of the earth. This combination of divine-council scene and godscomplaint takes a new approach to the suffering of the poor and the orphan, shifting the blame to the gods of the nations for the breakdown in the stabilizing structures of cosmic justice and deposing them, finally achieving the reorientation sought by so many laments. This reading obviates the need to posit a distinction between YHWH and El-there is no room or reason for such a distinction. Not only is El functionally invisible throughout the psalm, but קומה is not indicative of the deity's seated position throughout the narrative. ${ }^{47}$ Rather, it is a conventionalized complaint element that functions not as a reference to the physical posture of the subject of the imperative verb but as a call to action. ${ }^{48}$ While YHWH had exercised rule over the gods of the divine council up to this point within the Israelite worldview, the ousting of the gods allows YHWH to take over direct rule of the nations and restore the cosmic structures of justice. This restructuring of divine sovereignty facilitates the worship of YHWH by those residing outside the land of Judah and ultimately becomes the concluding declaration of the psalms of Asaph (Ps 83:19): "Let them know that it is you-whose name is YHWH-who alone are Most High over all the earth."

${ }^{46}$ See Judith M. Hadley, “The De-Deification of Deities in Deuteronomy," in Gordon, God of Israel, 157-74. As many scholars have noted, Ps 82 has thematic parallels in other ancient West Asian literature where deities are demoted or killed. Among the best discussions is Parker, "Beginning of the Reign of God."

${ }^{47}$ On El's muted role, see Parker, "Beginning of the Reign of God," 538; Smith, God in Translation, 136; Machinist, "How Gods Die," 202-3.

${ }^{48}$ Machinist notes that the use of קומה elsewhere in the Psalms reflects a "call for action from the deity" (Machinist, "How Gods Die," 198 and n. 25). 
Divine Council

Complaint

Elements

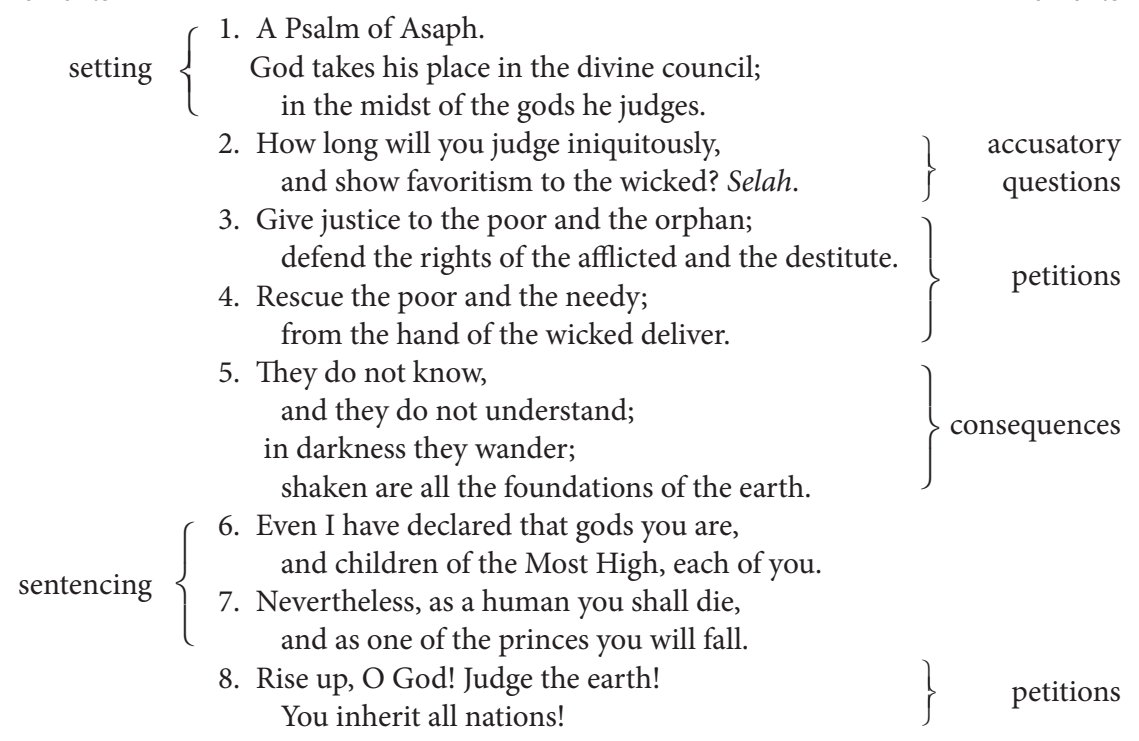

\section{Situating Psalm 82}

Frank-Lothar Hossfeld and Erich Zenger have argued convincingly for viewing two main compositional arcs within the psalms of Asaph, running from Ps 74 to Ps 76 and from Ps 79 to Ps $82 .{ }^{49}$ Both arcs begin with the communal complaints of Pss 74 and 79. In the second arc, Ps 80 is combined with Ps 79 as a continuation of that complaint. Psalms 75 and 81 are divine oracles, which provide the responses to the laments. In Ps 75:2-3, YHWH states, "I will appoint a time, and I, with uprightness, will judge. When the earth wavers, and all its inhabitants, it is I who steadies its pillars." Judgment is coming; YHWH alone may restore the order and steady the pillars of the earth. Psalm 81 admonishes Israel even as it responds to the lament: "My people did not listen to my voice. Israel did not satisfy me, so I turned them over to the stubbornness of their hearts, to follow after their own counsels. $\mathrm{O}$, that my people would listen to me, that Israel would walk in my ways!

\footnotetext{
${ }^{49}$ Hossfeld and Zenger, Psalms 2, 250, 257-58, 271, 305, 307, 317, 325-26, 336. See also Erich Zenger, "Psalm 82 im Kontext der Asaf-sammlung: religionsgeschichtliche Implikationen," in Religionsgeschichte Israels: Formale und materiale Aspekte, ed. Bernd Janowski and Matthias Köckert, VWGTh 15 (Gütersloh: Mohn, 1999), 272-92.
} 
I would soon humble their enemies, and turn my hand against their adversaries" (Ps 81:12-14).

Psalms 76 and 82 conclude the arcs with the intervention of YHWH. In the latter, YHWH indicts the gods of the nations and is called upon to take over in their place and restore the cosmic order. The final resolution is still off in the future; Ps 82 merely sets the table. In Ps 76, YHWH's abode has been established and the enemies have been vanquished. From the perspective of this psalm, the laments of the other psalms have been resolved (it was likely one of the later composed). It looks back on the fulfillment of the petition in Ps 82:8 when it declares in 76:9-10, "From the heavens you caused judgment to be heard; the earth feared and was silent when God rose up to judgment [בקום-למשפט אלהים], to save all the humble of the earth."

While this editorial theory fits Ps 82 comfortably into the thematic progression of the collection's compositional arcs, one might argue that the psalm was appropriated from an earlier context rather than composed to meet the rhetorical needs of the collection. Some linguistic and thematic features of the psalm make this unlikely, however. Most important to my discussion are Pss 74 and 79. Zenger described their relationship to each other as follows:

At the very beginning Psalm 79, with its reference to Yhwh's "inheritance" and its "defilement" looks back to Psalm 74. This is true also of the conclusion in 79:13, whose reference to the people as "the sheep of your pasture" looks back to 74:1. Both psalms develop their laments with the questions "why?" (74:1, 11; 79:10) and "how long?" (74:10; 79:5), circling around the topoi of divine wrath, the deriding of God, and blasphemy of the divine name. Both psalms urge Yhwh to intervene, with an explicit appeal to his office as judge $(74: 22 ; 79: 10-12) .{ }^{50}$

The differences between the two psalms, however, are also important. While Ps 74 is focused on offenses against YHWH committed by his generic enemies, Ps 79 emphasizes the suffering of the people at the hands of the nations, as well as the role of Israel's sin in that suffering. A primary appeal in Ps 79 is not just restoration but vengeance in the sight of all the nations. Here the gaze seems to be broadening beyond Israel and its immediate environs. For Zenger, Ps 79 is a theological interpretation of Ps 74 by a later author. Building on this, I suggest that Ps 82 is also looking back on Ps 79, but more directly on the first psalm of these compositional arcs, Ps 74. Psalm 82:8 seems to be a direct response to and fulfillment of the petition of Ps 74:22. The linguistic relationships and the resolution of the thematic tension within Ps 74 render it unlikely that Ps 82 was simply pulled off the shelf of complaints, dusted off, and conveniently inserted into the climax of this narrative arc.

Ideologically, Ps 82 fits best in an exilic setting, as well. As Peter Machinist argues, the petition in Ps 82:8 attempts to catalyze a transition in worldviews. It

${ }^{50}$ Zenger, Psalms 2, 305.

This article was published in JBL 137/4 (2018) 833-851, copyright @ 2018 by the Society of Biblical Literature. To purchase copies of this issue or to subscribe to JBL, please contact SBL Customer Service by phone at 866-727-9955 [toll-free in North America] or 404-727-9498, by fax at 404-727-2419, or visit the online SBL Store at www.sbl-site.org. 
moves YHWH from a position of rule over the divine council to one of exclusive sovereignty over the nations. Machinist does not feel that a chronological relationship with the other psalms can be posited, but I disagree. ${ }^{51}$ Psalms 74 and 79 attest to a view of YHWH as largely confined to Israel. Both psalms appeal to the vernacular of the Song of Moses (Deut 32:1-43) in connection with the destruction of the temple, referring to Israel as YHWH's "inheritance" without reference to any other nations under YHWH's immediate control. In these two psalms the nations do not call on the name of YHWH. In Ps 74 they revile that name. In Ps 79 they taunt YHWH and do not know him. The latter psalm pleads with YHWH to make his vengeance known among the nations. These texts push against the confines of a preexilic and early exilic worldview wherein YHWH is the God of Israel and the other gods are the patron deities of their own nations. This is the perspective when David laments in 1 Sam 26:19 that, in being kicked out of Israel-YHWH's "inheritance" (נחלה)—he is being forced to serve other gods. Similarly, in 2 Kgs 5:15-17, Naaman asks for cartloads of Israelite soil to facilitate YHWH's worship back in Syria, stating that there is no God in all the earth except in Israel. YHWH's political purview is the nation of Israel. I find no exceptions to this view in preexilic literature. YHWH is certainly presented as the god of gods who rules over the earth from the heavens, but the nations always take their directives from their own patron deities. The closest YHWH comes to governing another nation is through militarytype incursions, which more closely fit a limited purview. ${ }^{52}$

For the exiled Judahites in Babylon, the cosmic order has been rocked; only bringing down the political barriers that separate them from their deity back in Israel can steady it. Psalm 82 provides for that restructuring of the cosmos and envisions a world unknown to the author of Ps 74 . After the stewardships of the

${ }^{51}$ Machinist and White cite and reject Zenger's case for an Asaphite context for the composition of Ps 82, insisting that he attempts to make the case that the Asaphite psalms were all composed at or around the same time (Machinist, "How Gods Die," 236-37 n. 108; White, Yahweh's Council, 26). This, however, significantly misrepresents the case articulated by Zenger. His dating of the compositional histories of the psalms of Asaph spans from the eighth century BCE to the postexilic period (for instance, see Hossfeld and Zenger, Psalms 2, 226, 243-44, $263-$ $64,276,311,322,340-41)$.

${ }^{52}$ The clearest example is $2 \mathrm{Kgs} 3: 27$, where a military coalition that includes Israel has been promised victory over Moab by YHWH's prophet, but a last-minute sacrifice on the part of the Moabite king of his son and heir catalyzes a "great wrath" (קצף־גדול) that compels the Israelites to retreat. The text suggests that the offering of the king's son successfully catalyzed a response from the Moabite patron deity that drove off the invading forces. On this pericope, see Mordechai Cogan and Hayim Tadmor, II Kings: A New Translation with Introduction and Commentary, AB 11 (Garden City, NY: Doubleday, 1988), 40-52; John Barclay Burns, "Why Did the Besieging Army Withdraw? (II Reg 3,27)," ZAW 102 (1990): 187-94; Jon D. Levenson, The Death and Resurrection of the Beloved Son: The Transformation of Child Sacrifice in Judaism and Christianity (New Haven: Yale University Press, 1993), 14-17; Francesca Stavrakopoulou, King Manasseh and Child Sacrifice: Biblical Distortions of Historical Realities, BZAW 338 (Berlin: de Gruyter, 2004), 176-77; Smith, God in Translation, 116-18.

This article was published in JBL 137/4 (2018) 833-851, copyright ( 2018 by the Society of Biblical Literature. To purchase copies of this issue or to subscribe to JBL, please contact SBL Customer Service by phone at 866-727-9955 [toll-free in North America] or 404-727-9498, by fax at 404-727-2419, or visit the online SBL Store at www.sbl-site.org. 
gods over the nations are vacated, the psalmist calls upon YHWH to take them over and extend his inheritance over all the earth. In this sense, Ps 82 represents the climax of the psalms of Asaph. The two narrative arcs running from Ps 74 to Ps 76 and from Ps 79 to Ps 82 reach a head in Ps 82 with the universalization of YHWH and his exaltation over the nations of the earth. There is little evidence for significant redaction after the initial composition, and the psalm should therefore be understood as composed precisely to serve the collection's rhetorical exigencies. ${ }^{53}$ Thus, in agreement with Zenger, a date of composition in the late exilic or early postexilic period is most likely. ${ }^{54}$ Even if one insists on an unrecoverable preAsaphite version, however, the parallels shared by the psalms would have been salient to any hearer or reader confronted with both psalms in their current positions within the Asaphite collection. The rhetorical function of Ps 82, therefore, as a response to Ps 74 and the climax of the psalms of Asaph would have been the dominant reading upon its inclusion in the corpus.

\section{Conclusion}

Psalm 82 was not written in a vacuum but in a literary context that facilitated its interpretation by its earliest hearers and readers. It shares a number of linguistic and thematic relationships with that context that have long been overlooked by scholars more interested in what the psalm reveals about early Israelite conceptualizations of deity than in how the text was intended to function. The psalm's interpretive challenges have endured for a few reasons. For instance, the psalm is difficult to interpret precisely because it makes use of conventional literary forms in unconventional ways, exactly as one would expect from a revolutionary reframing of the

${ }^{53}$ Apart from the plausible reconstruction of עדת־אלים in verse 1 based on the LXX's $\sigma u \nu \alpha \gamma \omega \gamma \tilde{n} \theta \varepsilon \tilde{\omega} \nu$.

${ }^{54}$ Objections to this dating on the grounds that the mythological and polytheistic parallels with earlier West Asian literature are too strong (Goulder, Psalms of Asaph, 160; Trotter, "Death of the אלהים", 233) privilege the assumption of an early and strict concept of monotheism that would have precluded the preservation of older themes. Of course, older themes are frequently preserved (Ps 74, for instance, makes use of the early Chaoskampf tradition [see n. 30 above]). I would refer the reader to Peter Hayman, "Monotheism-A Misused Word in Jewish Studies?" JJS 42 (1991): 1-15, here 8: "In some cases, we can see the old Canaanite gods still there in rabbinic Judaism, even retaining their old titles. Prince Yam, for example, lives on in the Babylonian Talmud and in some of the midrashim, and his opposition to Israel is located precisely where we should expect it: at the Sea of Reeds.... The mythological overtones of the crossing of the are thus preserved in rabbinic Judaism as are numerous other remnants of older Canaanite beliefs.... There are rich, as yet unexplored, pickings in rabbinic midrash for scholars interested in the Canaanite background to Israelite religion." See also Jonathan Ben-Dov, "The Resurrection of the Divine Assembly in the Divine Title El in the Dead Sea Scrolls," in The Comparative Perspective, vol. 3 of Submerged Literature in Ancient Greek Culture, ed. Andrea Ercolani and Manuela Giordano (Berlin: de Gruyter, 2016), 9-31.

This article was published in JBL 137/4 (2018) 833-851, copyright ( 2018 by the Society of Biblical Literature. To purchase copies of this issue or to subscribe to JBL, please contact SBL Customer Service by phone at 866-727-9955 [toll-free in North America] or 404-727-9498, by fax at 404-727-2419, or visit the online SBL Store at www.sbl-site.org. 
cosmological structures of divinity. In order for Ps 82 to gain purchase in the contemporaneous literary milieu, the author had to draw stabilizing connections with genres and motifs already in circulation but had to do so in a way that broke new conceptual ground and helped facilitate the overturning of long-held theological frameworks. Externally, scholars have struggled with the psalm because the divine-council framework has generally overshadowed other genre considerations, because an Asaphite compositional context demands a later date than many scholars would like, and because the placement of the complaint in the mouth of YHWH represents a significant innovation on the genre. This has resulted in less-thansatisfactory interpretive models that have been forced to draw literary contexts from second-millennium texts from Ugarit and elsewhere.

As this examination has shown, the use of עד־מתי in accusatory questions (followed by serial imperative petitions, including קומהי) and the conventionalized call to action appeal directly to the elements of the complaint genre that are featured so heavily in the psalms leading up to Ps 82 . If we remove the divine-council framework (vv. 1 and 6-7) and direct the remaining verses at YHWH rather than at the gods, the psalm would undoubtedly be classified as a psalm of complaint. As it stands, it was most likely composed in response to those other Asaphite complaints that blame YHWH for the destruction of Jerusalem and the exile of his people. The cosmological pillars of justice were rocked by these events, but the traditional complaint format could not provide the desired resolution. A new approach was formulated.

Rather than blame YHWH, Ps 82 expands the responsibility for the breakdown in justice to the other members of the divine council, who were equally responsible for regulating justice within their respective purviews and maintaining the cosmic order. The enemies in Pss 74 and 79 came from outside of Israel and thus outside of YHWH's purview, making their atrocities the responsibility of their respective patron deities. The complaint was placed in the mouth of YHWH and directed at the gods. Within the framework of the divine council, YHWH could pass judgment and effect the cosmic reorientation that Israel's liturgical pleas could not. By divine fiat, the gods' immortality was revoked, which allowed YHWH to expand his inheritance over all the nations of the earth and directly administer justice to his people scattered abroad. Psalm 82 is more than a divine-council scene, a prophetic liturgy, or a peculiar mixing of psalm and oracle; it is a gods-complaint that facilitated the most important turning point in the history of the conceptualization of the God of Israel. 